\title{
Analysis of late mid-Neolithic pottery illuminates the presence of a Corded Ware Culture on the Baltic Island of Gotland
}

\author{
Erik Palmgren ', Helene Martinsson-Wallin ${ }^{2}$ \\ 1 Visby, SE \\ erik14.palmgren@gmail.com \\ 2 Department of Archaeology and Ancient History, Uppsala University, SE \\ helene.martinsson-wallin@arkeologi.uu.se
}

\begin{abstract}
In this paper, we discuss variations seen in the ornamentation and modes of manufacturing pottery from the end of the mid-Neolithic 4600-4300 BP on the Island of Gotland in the Baltic Sea. The Pitted Ware cultural groups have been discussed as a western influence from the Swedish mainland, but the aDNA on skeletal remains point to eastern influences. We analyse and discuss pottery from the well-investigated Ajvide Pitted Ware site and what these variations mean in term of intra- and inter-island relationships, ethnicity and change, and we suggest the development of what could be described as a hybrid culture.
\end{abstract}

IZVLEČEK - V članku predstavljamo razlike v ornamentih in izdelavi lončenine s konca srednjega neolitika, 4600-4300 BP na otoku Gotland na Baltskem morju. Kulturne skupine jamičaste keramike so bile tu interpretirane kot zahodni vpliv s celinske Švedske, vendar stara DNK v neolitskih človeških kostnih ostankih kaže na vzhodne vplive. Analiziramo lončenino z dobro raziskanega najdišča jamičaste keramike Ajvide in pojasnjujemo, kaj te razlike pomenijo na otoku in med otoki, kako so povezane s populacijskimi premenami in kulture opišemo kot hibridne.

KEY WORDS - Pitted Ware Culture; Corded Ware Culture; Battle Axe Culture; hybrid culture; pottery; identity; Gotland; Baltic Sea; mid-Neolithic

\section{Introduction}

The focus of this article is an analysis of decorative designs on pot-sherds from the well-documented Pitted Ware Culture (PWC) site of Ajvide on South West Gotland Island in the Baltic Sea, which is dated to the mid-Neolithic (5300-4300 BP). We use this case study to address the following questions: is the pottery with cord imprints found at Gotland PWC sites a feature that is an influence from the Funnel Beaker Culture (FBC) or the Battle Axe Culture BAC, which is a Scandinavian variety of the Corded Ware Culture (CWC). Secondly, why is pottery with cord imprints found at Gotland PWC sites and not at the Swedish mainland PWC sites?

To arrive at better models of interpretation of human colonisation and migration $v s$. the transmission of ideas and trading of prestige goods and commodities during Neolithic in Scandinavia, we suggest that it is increasingly important to make detailed analyses of the genetic, material cultural and environmental evidence alike and their temporal variations. Here we mainly focus on pottery, but we discuss other types of material culture, radiocarbon dates and isotope and genetic studies.

The typical pottery style of ornamental design of PWC pots include pits, incisions and stamps made with bones and combs tools, whereas PWC pottery made by groups on the also includes sherds with cord imprints. The cord imprints are patterns that are generally typical of the $\mathrm{FBC}$ groups that were contemporaneous with PWC in the earliest phase 
of the mid-Neolithic (MN A c. 5300-4800 BP) and the BAC, which was contemporaneous with the PWC on the Swedish mainland during the late mid-Neolithic (MN B $c$. 4800-4300 BP).

The earliest human traces on Gotland were found at the Stora Förvar cave site on the islet of Stora Karlsö and date to the Scandinavian mid-Mesolithic phase, (c. 8000 BP) (Fig. 1 and Tab. 1). This small raised limestone islet lies approx. 10km south-west of the Gotland mainland. During the following phase, the Late Mesolithic (c. 7500-6000 BP), there are finds of human activities also on mainland Gotland, especially in the north. The Scandinavian Early Neolithic (c. 6000-5500 BP), human occupation of Gotland was located close to an inshore lake system in the centre of the island (Österholm 1989.74), where the first evidence of pottery on Gotland was found. The pottery has cord imprints and is from the $\mathrm{FBC}$ tradition, while other finds at these sites indicate flint tool manufacturing in conjunction with hearths with burnt bone fragments and nut shells (Thorsberg 1997; Österholm 1989; Lidman 2014). The FBC groups have been interpreted as farming communities that utilised domesticate animals and had megalith burial customs (Martinsson-Wallin, Wallin 2010).

\begin{tabular}{|l|c|c|}
\hline $\begin{array}{l}\text { Scandinavian } \\
\text { Stone Age phase } \\
\text { on Gotland }\end{array}$ & BP & BC \\
\hline Mid-Mesolithic & c. $8000-7500$ BP & c. $6000-5500$ BC \\
\hline Late Mesolithic & c. $7500-6000$ BP & c. $5500-4000$ BC \\
\hline Early Neolithic & c. $6000-5500$ BP & c. $4000-3500$ BC \\
\hline Mid-Neolithic A & c. $5500-4800$ BP & c. $3500-2800$ BC \\
\hline Mid-Neolithic B & c. $4800-4300$ BP & c. $2800-2300$ BC \\
\hline
\end{tabular}

Tab. 1. Scandinavian Stone Age phases and their approximate BP and BC dates.

to the lakes and wetlands (Palmgren 2014a). Here, the discussions have focused on whether a new group of people from the corded ware BAC tradition migrated to Gotland Island and mixed with PWC groups or whether only BAC material culture, a few marriage partners and ideas that found its way to Gotland Island.

\section{Pitted Ware Culture}

The term Pitted Ware Culture was coined by researchers in the early 1900s, when Stone Age sites with pottery decorated with distinct pits were found in east mainland Sweden (Malmer 2002). These sites

The FBC pottery tradition and Neolithic lifestyle ended in the Scandinavian mid-Neolithic (c. 5500-4300 BP) and human settlement on Gotland has been described as part of the PWC, sub-Neolithic tradition. According to radiocarbon dating, the FBC and the PWC co-existed during the earliest part of this time frame (mid-Neolithic A $c$. 5500-4800 BP) and the discussion has focused on whether the FBC groups were the ancestors of the PWC or the PWC ancestors were from an earlier Mesolithic group on the island. Another version is that the PWC groups migrated to Gotland Island in the mid-Neolithic and had no previous ancestors on the island. Current research data support the latter hypothesis.

The PWC tradition dominated Gotland for some 500 years during the mid-Neolithic. At the end of the mid-Neolithic (MN B $c$. $4800-4300 \mathrm{BP}$ ) traces have been found of material culture typical of the BAC, such as corded ware and typical battle axes. The former are found at coastal PWC settlements, but the latter are found all over Gotland, especially towards the hinterland close

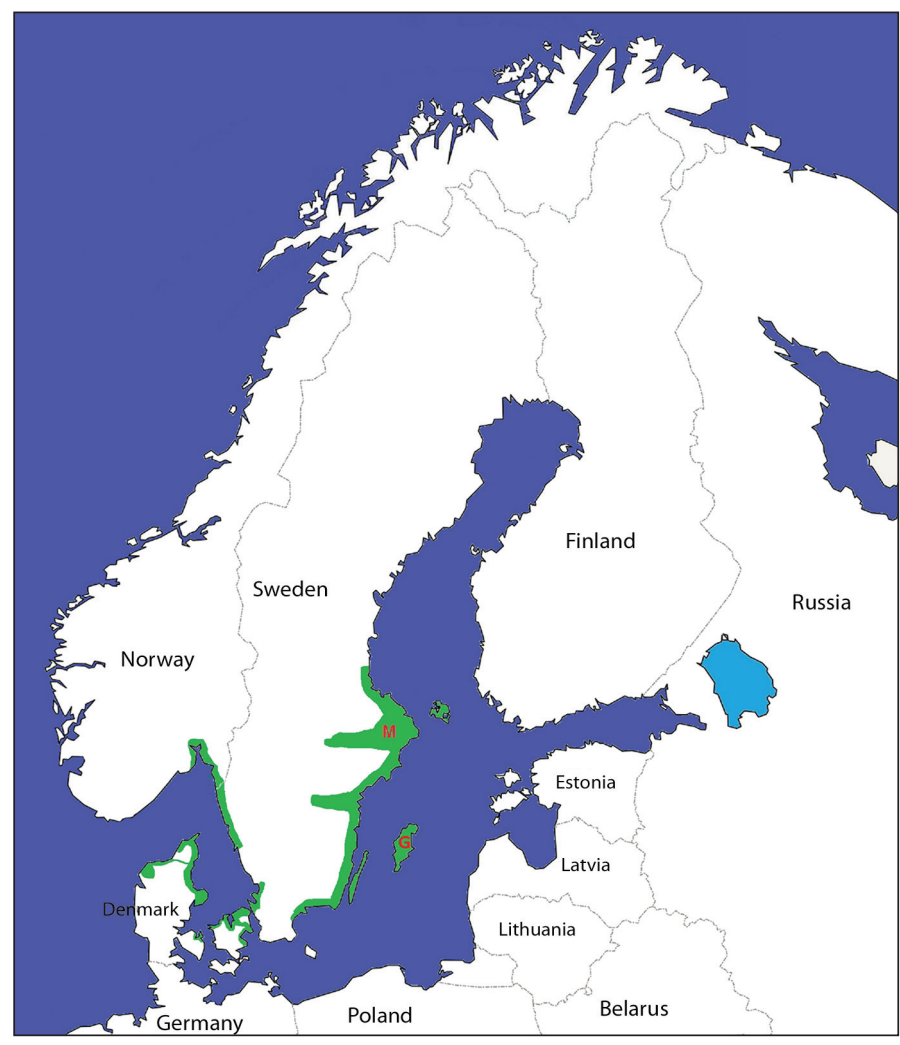

Fig. 1. Map of the distribution of PWC tradition. The green colour indicates the approximate distribution of PWC culture. M stands for 'Mälar Valley', G for 'Gotland' (after Palmgren 2015). 
were found inland, but due to shoreline displacement it was calculated that they were coastal bound during the Neolithic. The PWC groups have been discussed as belonging to a homogeneous culture, and these groups were distributed over large parts of Northern Europe, but with regional variations among the pottery assemblages (Fig. 1). The regional traits can be detected in variations in the ornamentation and durability of the ware. The archaeological remains of PWC groups have been found on the east and south coasts of Sweden, and on the Baltic islands of Åland, Gotland and Öland, but also on the west coast of Sweden, north-eastern Denmark and south-eastern Norway (Malmer 2002.120-122). This tradition is dated to the mid-Neolithic (c.5300$4300 \mathrm{BP}$ ), the earliest sites being found in areas in the Lake Mälaren Valley (Hallgren 2011.32) (Fig. 1).

The east coast mainland Sweden pottery from the PWC groups has been divided into various types based on pottery from the Fagervik site (Fagervik II-IV) and with regard to the different stratigraphic levels in which they were found (Bagge 1951). Fagervik I belongs to the FBC tradition and Fagervik $\mathrm{V}$ belongs to the BAC tradition, so Fagervik II-IV has been interpreted as stemming from the PWC tradition. However, the south and west Swedish pottery from the PWC tradition does not conform to the template of the Fagervik pottery style. Given that PWC pottery ornamentation actually varies from place to place, it has been suggested by Welinder (1973.56) that the PWC tradition should be divided into East Swedish, South Swedish and Gotlandic and a North Sea group.

A marked difference between the East and West Swedish PWC ware is that the latter is dense, while the former is both dense and porous (Strinnholm 2001). This was because they were tempered in different ways. For example, some ware found in eastern Sweden and on Gotland was tempered with material that has been degraded due to taphonomic processes. This process is common in pottery tempered with crushed limestone, which is the typical temper of the PWC pottery found on Gotland. The choice of this type of temper is not surprising, since most of the bedrock on Gotland is limestone, but sources of quartz and granite are limited. However, the latter two are among the most common materials for temper on the east coast of Sweden during the late midNeolithic (Ytterberg 2007.392).

Archaeological research has shown that these groups had a sub-Neolithic life style, including marine hunt- ing and foraging. The animal bone residues found at these sites show that their subsistence was based mainly on seal hunting and fishing. They also utilised domesticate animals such as pig, dog and cattle to a minor extent, but no traces of crops have been found.

The PWC sites on Gotland are located on the coast and the activities are interpreted as settlement/hunting sites in the early phase and burial sites during the later stages (Martinsson-Wallin 2008; Wallin 2015; Wallin, Martinsson-Wallin in press). The early Ajvide pottery shows various traits that are similar to the PWC pottery found at sites on the Swedish east coast. Since the Ajvide site is located in the southwestern part of Gotland and close to the Stora Karlsö site (which was in continuous use during the midNeolithic), and sites on the northernmost point of Öland Island, it is likely that they had close contacts between east Sweden and Ajvide/Stora Karlsö sites during this time (Papmehl-Dufay 2003).

\section{The PWC Ajvide-site - graves and pottery}

The earliest excavations at Ajvide were carried out in 1923. Excavations were not resumed until 1983, when large-scale work began, continuing with some minor breaks until 2008 (Österholm 1989; 2008; Burenhult 1997; 2002; Ajvide Database 2009). The field work of over 20 years was carried out in the form of field training by Stockholm and Gotland universities. The very rich cultural layers, which can be over half a metre thick, are typical at most sites with PWC graves on Gotland, but are less common along the Swedish coasts. The Ajvide site has never been subjected to modern ploughing, and below the topsoil of approx. $20 \mathrm{~cm}$ of mixed material, the cultural layers were intact. A large quantity of archaeological finds was recovered, consisting of around $2300 \mathrm{~kg}$ of bone fragments, $3300 \mathrm{~kg}$ of ceramic sherds and $200 \mathrm{~kg}$ of flint (Ajvide Database 2009). The total size of the excavated area is approximately $3000 \mathrm{~m}^{2}$, although this is only a small part of the estimated $200000 \mathrm{~m}^{2}$ size of this site (Wallin 2015).

The Ajvide site is situated on a cape close to the shore, and phosphate analysis (Österholm 1989) has shown that the area of utilisation follows the shoreline displacement and topography of the cape in a north-south direction (Fig. 2).

Several areas with dark 'fatty' soil have been found on the site, which have been interpreted as areas for ritual activities such as ritual butchering. To date, 
four (possible five) 'dark areas' have been found. These areas yielded a larger amount of pottery than other areas, and the radiocarbon dates indicate that these areas were utilised only in the latter part of the mid-Neolithic (MN B) (Wall, Martinsson-Wallin in press).

\section{The graves}

Over 200 PWC graves have been found on Gotland, and with their high frequency and rich grave goods (Stenberger et al. 1943; Janzon 1974; Wallin, Martinsson-Wallin 1992; Österholm 1989; 2008; Burenhult 2002; Wallin in press) they differ significantly in comparison with PWC graves found along the Swedish mid-Neolithic coasts (Papmehl-Dufay 2003. 186). To date, 85 graves have been excavated at the Ajvide site, the largest PWC grave site in northern Europe. Among these graves, eight features have been interpreted as graves with grave goods, but without human remains (cenotaphs). In total, 89 individuals have been found in the excavated graves (Burenhult 2002; Österholm 2008; Wallin, Martinsson-Wallin in press; Wallin in press).

The most of the human skeletal remains were in a supine position, al-

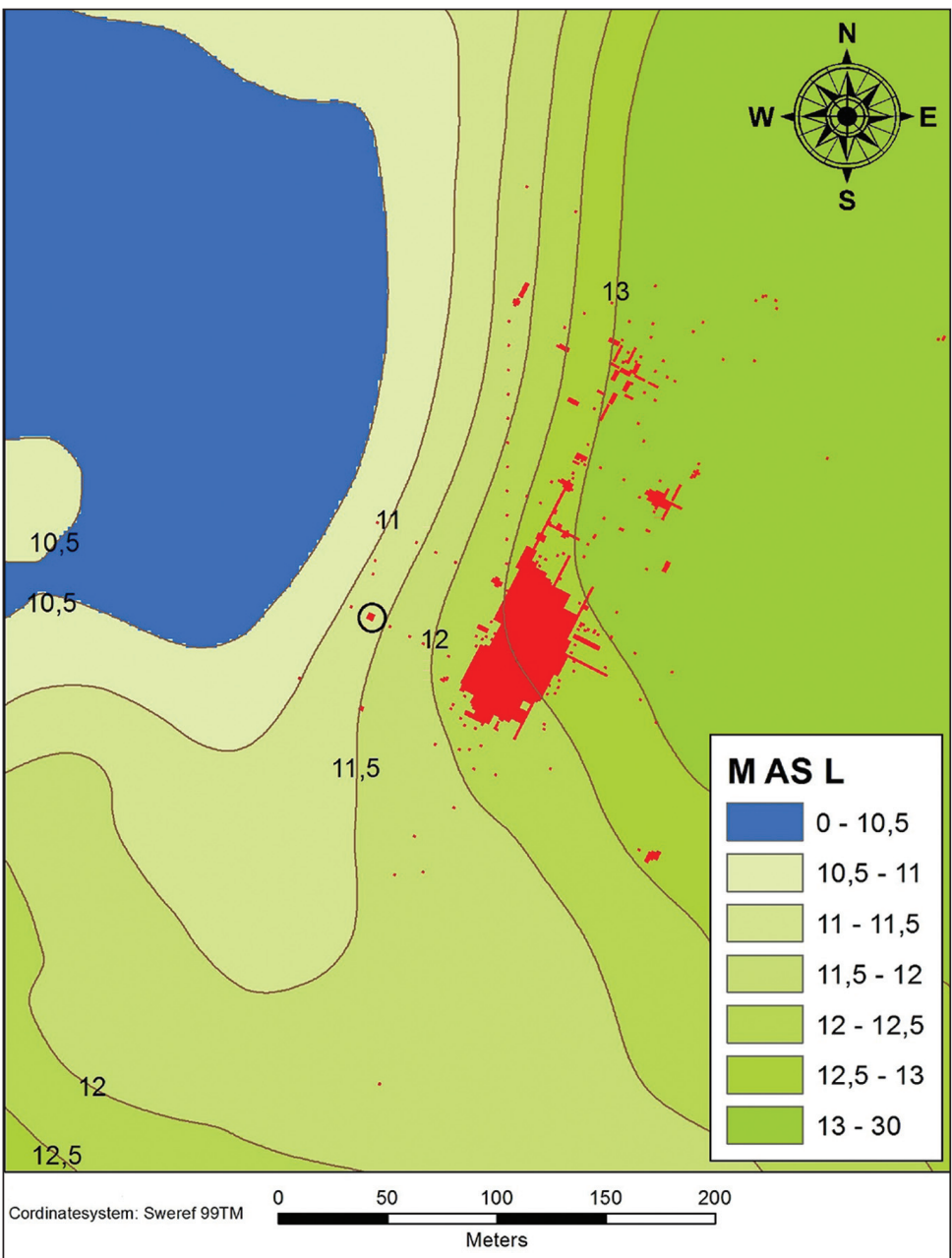

Fig. 2. Mas L values at the Ajvide site. The red colour represent excavated areas; cast study trench is marked with a black circle. The site was above 10.5m level during the late MN B (after Gustavsson, Palmgren 2015). though in at least five of the graves the deceased was buried on the side in a crouching position (hocker position) (Burenhult 2002; Österholm 2008). In the latter part of the mid-Neolithic, the PWC groups on the Swedish mainland lived side by side with BAC groups. The latter typically placed their dead in a crouching position, facing east. In comparison with the five Ajvide burials in a crouching position (two men, two women and one juvenile), they are facing north (Burenhult 2002; Palmgren 2014a.69, 114; Wallin 2015).

Four of these graves were found on the margins of the burial area, which may indicate that they were late burials. Radiocarbon dating was carried out on three of the graves: no. 28, (Burenhult 2002.100, Figs. 62b, 128), no. 36 (Burenhult 2002.103, 134, Figs. 70a, b) and no. 73 (Wallin, Martinsson-Wallin in press). The individual in grave 28 is dated to $c$. 5200-4500 BP (i.e. the early-mid phase of MN) and the ${ }^{13} \mathrm{C}$ isotope analysis shows that this individual had a terrestrial diet. Grave 36 is dated to $c$. 4800$4400 \mathrm{BP}$ (i.e. early-mid $\mathrm{MN} \mathrm{B}$ ) and $13 \mathrm{C}$ isotope analysis shows that this individual had a marine diet. This is the only grave at the Ajvide grave site that was associated with a ceramic sherd with ornamentation resembling corded ware imprints. The date of the human bone remains from the third (grave 73 ) is c. $4500-4300 \mathrm{BP}$ (i.e. late $\mathrm{MN} \mathrm{B}$ ) and ${ }^{13} \mathrm{C}$ isotope analysis shows that this individual had a terrestrial diet. Both individuals in grave 28 and grave 73 show a tendency to a terrestrial diet, but the former is earlier and the latter came from one of the later graves. Thus the evidence is inconclusive, but see the further discussion below on the find material in grave 36 .

\section{The grave goods}

The grave goods found at Ajvide are varied and numerous. Considering that the PWC was a hunter- ga- 
therer culture, artefacts such as flint fish hooks, arrow heads and axes etc. are among the grave goods. The ${ }^{14} \mathrm{C}$-dates on the graves show that a trend in the custom of providing the deceased with numerous durable grave goods declined during the latter part of the MN B (Wallin in press). Gotland is rich in Ordovician flint, but the quality is poorer and it cracks more easily compared with south Scandinavian flint. All the axes found in the graves are of south Scandinavia flint, which is a durable material and it is probable that these axes were considered exotic status objects.

Some grave goods recovered from Ajvide most likely originated from the BAC and perhaps from the Single Grave Culture (SGC) in Denmark. Although the burial area yielded artefacts from the Danish and Swedish variants of the Corded Ware Culture (CWC) alike, the burial area at Ajvide actually have fewer artefacts that resemble the Danish and Swedish CWC in comparison with other PWC sites with graves on Gotland (Palmgren 2014a.5762). In fact, there seems to be a major difference between the southern and northern parts of Gotland concerning typical BAC artefacts (Palmgren 2014a) (Fig. 3). Artefacts found at the Ajvide site that can be described as characteristic of BAC are described below.

A faceted grindstone was found in grave 19 (Burenhult 2002.96, 119120, Figs. 50-5) of a type characteristic of the BAC on the Swedish mainland. It is one of four faceted grindstones found on Gotland. Two of these, which are of an early model (four sides), were found at the burial area at Ajvide and at the Visby PWC site. In both cases, the grindstone was placed on the deceased man's right shoulder with their hand placed on it (Janzon 1974; Burenhult 2002.119, Fig. 50). The remaining two grindstones are of late models (i.e. have more than four sides), but were only stray finds (Palmgren 2014a).

Ten excavated graves at Ajvide contained amber beads in various forms (Ajvide Database 2009). Amber is not a natural resource on Gotland, and probably originated from southern Sweden and/or Denmark, from where other imported exotic artefacts originated, although it cannot be ruled out that some of the amber artefacts originated from the Baltic and/ or Poland (Axelsson, Strinnholm 2013.149).

Six excavated graves on Ajvide contained flint axes (Ajvide Database 2009). All of them are thick-butted, a common characteristic of late FBC or BAC traditions. Several flint axes found on Gotland probably originated in Denmark, such as at the Västerbjers PWC site. Several artefacts, including flint axes which have been linked with the Danish SGC due to their shape and ${ }^{14} \mathrm{C}$-dating of the human skeletal remains with which they were found (Stenberger et al. 1943; Ebbesen 2006; Palmgren 2014a). However, none of the axes at Ajvide had straight edges, which probably means that these did not originate in Denmark.

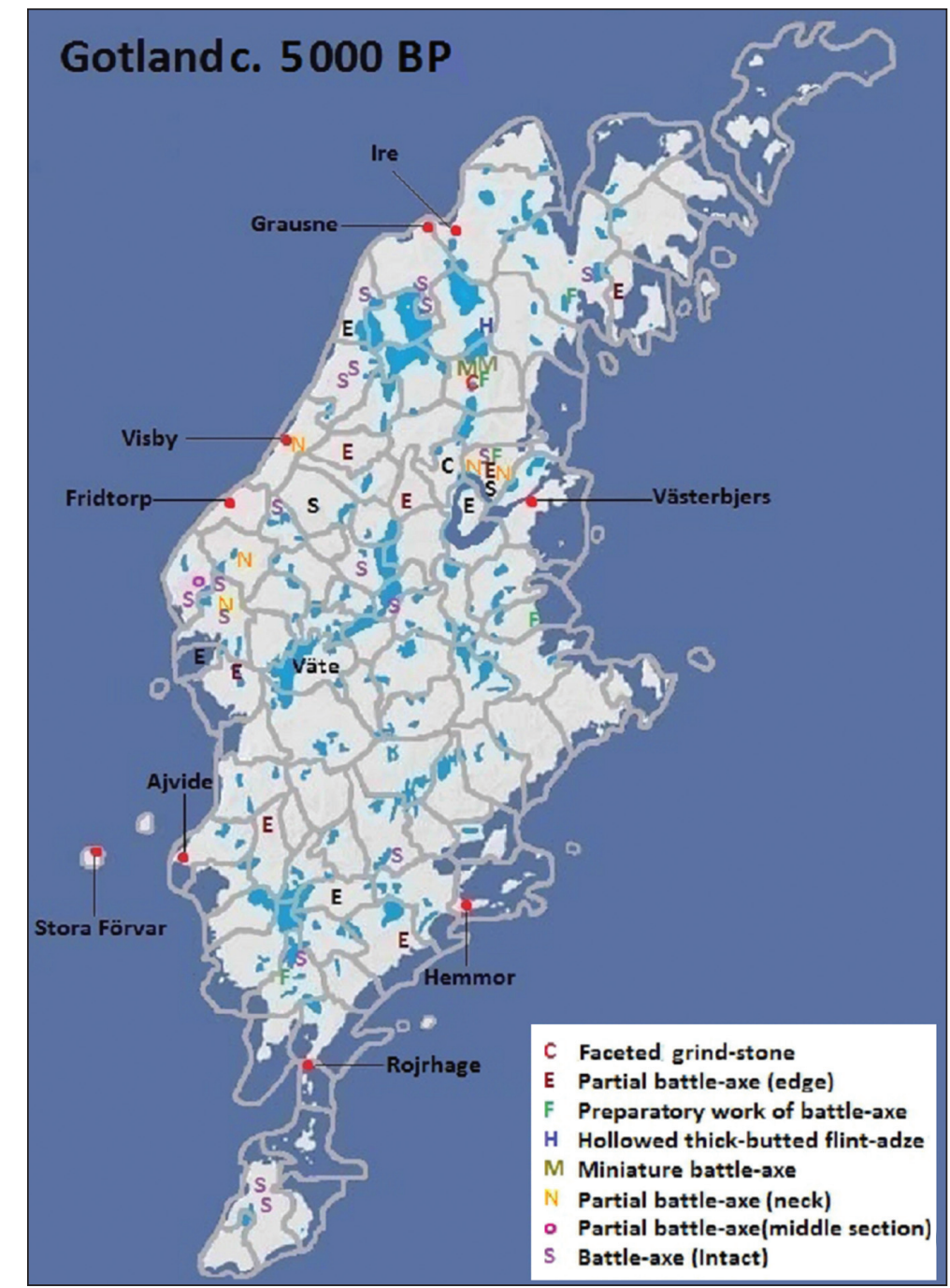

Fig. 3. BAC artefacts on Gotland. Grey lines represent parish borders. The letters in black colour represent only parish finds and not the exact location (from Palmgren 2014b). 
As mentioned earlier, grave 36 contained a ceramic sherd decorated with imprints which resemble corded ware. There are several aspects that are interesting regarding this item. Firstly, it was tempered with crushed limestone, which is the most common temper in the PWC ceramics, but not FBC or BAC pottery. Secondly, it was found by the legs of a deceased woman (marked with a red circle, see Fig. 4) who had been placed in a crouching position, which is common in BAC. Thirdly, the sherd is decorated with what appears to be a right-twisted corded imprint, but the imprint was made by another tool to make it resemble corded ware. It is possible that the deceased originated from the BAC although 'real' cord imprints were not used in the PWC in this early contact phase, hence the crouching position, but the imprints that resemble to corded ware were used to show the woman's origin. The date could fit into the earliest Corded Ware Cultural tradition from continental Europe (c. $4800 \mathrm{BP})$ but the $13 \mathrm{C}$ isotope value indicated that she had a marine diet, which is typical of the PWC. Perhaps future genetic studies can provide further information on the origin of this individual.

\section{The case study pottery analysis}

Pottery from the Ajvide site has previously been subjected to formal analysis regarding the pottery ornamentation design and some technical analysis of the clay (Sharp 1985; Österholm 1989.97-117; Lidman 2013). An ornamentation design scheme was worked out by Österholm (1989.110). The obvious ornamen-

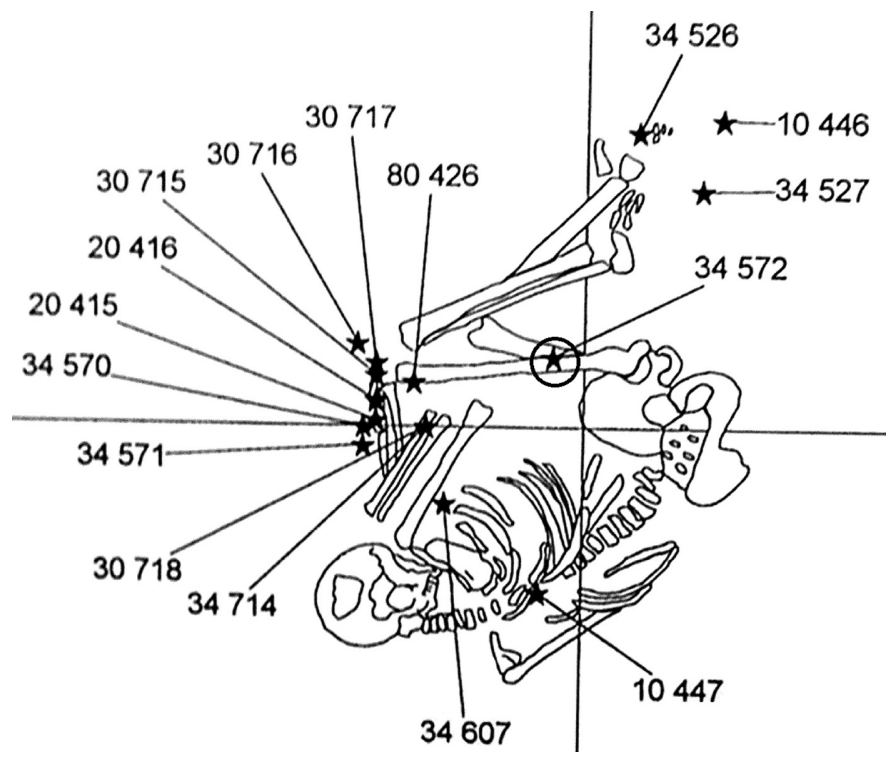

Fig. 4. Grave 36 on the Ajvide site. Circle shows where the sherd with imprints resembling corded ware was found (from Burenhult 2002.134). tation on the PWC pottery (which also provided the name for the culture) are pits, generally $c .0 .3-1 \mathrm{~cm}$ in size (Fig. 7), decorating the rim, neck and shoulder of the vessels. Besides the pits, various incisions and stamps were created with bones and combs etc. (Österholm 1989.103-110).

The MN B pottery used in our analyses was from a test pit $50 \mathrm{~m}$ the west of the area that has been interpreted as the core area of the site (Fig. 2). A test pit, $1 \mathrm{~m}^{2}$ in size, was excavated by Österholm in 2000 with the aim of finding the western limits of the site. The test pit revealed large quantities of pot sherds, but numerous bone remains were also found. of particular interest was that several sherds bore designs that were not previously described. In the light of the new finds, the test pit was extended by an additional eight $\mathrm{m}^{2}$ in the following year. The intention of the excavator, Österholm, was to carry out a further analysis of the interesting sherds, but this was not done until 2014 (Palmgren 2014b).

The sherds recovered from the test pit weighed $16 \mathrm{~kg}$, which can be compared with the $250 \mathrm{~kg}$ of pot sherds from Ajvide previously analysed (Österholm 1989). The material used for the analysis comprises 487 decorated sherds found between 11.14-10.89m above sea level (m.a.s.l.) (second and third levels of the cultural layer) (Palmgren 2014b). The same criteria and ornamentation design scheme as worked out by Österholm (1989.110) was used in our analysis. The analysis of the sherds from the test pit showed that cord imprints were the most common ornamentation; of 487 analysed decorated sherds, 102 have cord imprints (approx. 20\%). Sherds with cord imprints appear only as a single pattern or combined with pits. It was estimated that the 102 sherds derived from between 20-30 vessels, but only one out of five imprints could be defined as right-twisted (Palmgren 2014b).

A few, but not the majority, of the sherds have been affected by wave action. It is likely that the sherds were deposited close to the contemporary shoreline and since there were more sherds affected by wave actions in the western quadrants, which held fewer sherds and were closer to the sea than the others. The shoreline at the Ajvide site has been estimated to around $10.5 \mathrm{~m}$ a.s.l. at 2400-2300 BC (Palmgren 2014b.40) and the bottom of the cultural layer in this test pit was at $10.89 \mathrm{~m}$. a.s.l. Two ${ }^{14} \mathrm{C}$-datings of 
bone remains from the cultural layer, one pig tusk and one tooth from a pig mandibular found at a slightly different depths in the centre of the excavated squares, were used as samples for dating. Pig bones were preferred, since previous isotope analyses of pig bones from similar contexts on Gotland have shown that the pigs did not eat a marine diet and we wanted to avoid the reservoir effect (Eriksson 2004; Wallin, Martinsson Wallinin in press). The results of the ${ }^{14} \mathrm{C}$ analysis showed that both layers dated to between $c$. 4630-4460 BP (see Tab. 2).

Fifty-seven different designs were defined on the sherds from the test pits, of which 18 were new (Palmgren 2014b.27-30). This analysis increased the number of pottery ornamentation designs to around a hundred different patterns found so far at the site. However, some designs are quite similar in shape and form, which might reflect creativity and change in the decorative scheme over time that may possibly be related to various pot-making traditions within Gotlandic PWC.

The sherds used in this analysis were found close to the sea, and given them a.s.l. value and ${ }^{14} \mathrm{C}$-datings, the trench was most likely under water during the earliest phase of the site. The pottery found at this location thus reflects a late phase (i.e. late MN B). Earlier analysis by Österholm $(1989.108,110)$ showed that a few pot-sherds with cord imprints were found at Ajvide (ornament type 63-65) at the larger excavated areas called areas D and C (see Figure 2 the larger red areas). A few sherds of the types 64-65 (vertical cord imprints) have been found in the early MN A level and the younger MN B level, but type 66 (horizontal cord imprint) is mainly linked to the younger MN B level. Type 66 is more common than 63-65, but cord imprints are rare compared to other designs (Österholm 1989. 112-114).

\section{New techniques}

Österholm was of the opinion that the earliest pots at Ajvide had funnel-like necks (1989) but this was not shown on the rim sherds found in the test trench. This, together with the location close to the late MN B sea shore, the radiocarbon dates and the ornamentation designs on the pots which among others show cord imprints, indicate that the pottery in the test pit relates to the late phase of the PWC site. The pottery from the trench also revealed four new techniques.

(1) The surface of some sherds can be labelled as degenerative and 'sloppy' since the patterns are blurred and are crudely finishished.

(2) A number of sherds also have a cruder surface in general, even if the patters are more distinct than the sherds referred to above. The potter did not take so much care to polish the surface as before. It is likely that this was due to the fact that the potters stopped using polishing stones and instead used other tools of organic material when they finished the pot surfaces (Palmgren 2014b; 2015).

3 Four sherds have an additional coarse slip of clay (barbotine) on the outer surface which has been taken to mean that the pot was ready made with decorations and dried, whereupon an extra layer of clay was applied on the pot (Fig. 10). This type of pottery was common during the Bronze Age (3700$2500 \mathrm{BP})$ and perhaps at the end of the late Neolithic (4300-3700 BP), but not found on pots dated to earlier time frames. It should be noted that a coarse slipped outer surface makes the pot easier to handle and keeps the contents cool (Hulthén 2011. 32), so this might be a utilitarian aspect.

(4) A number of sherds also have quartz temper, which is very uncommon in Gotlandic PWC pot manufacturing. On the other hand, this type of temper is very common in $\mathrm{FBC}$, while some $\mathrm{PWC}$ pots from the Stora Karlsö cave site were also tempered with this material (Palmgren 2015). Grog is a common temper in BAC pots, but mainland BAC pots also have tempers with crushed quartz.

Aside from the 'sloppily' made or 'degenerative' pottery, the sherds from these vessels were also poorly fired and the proportion of temper is large. It can also be added that, when analysing sherds from Stora Karlsö, a corded imprint pattern was found underneath an extra clay slip layer which had been added to the outside of the vessel (Palmgren 2015.9).

\begin{tabular}{|lcccc|}
\hline Layers & Lab nr. & BP & BC & Probab. \\
\hline Layer 2 (11,11-11,02 MASL) & Ua-48709 & $4002 \pm 38$ BP & $2630-2450$ BC & $95.40 \%$ \\
\hline Layer 3 (10,96 MASL) & Ua-48708 & $4020 \pm 43$ BP & $2670-2460$ BC & $92.80 \%$ \\
\hline
\end{tabular}

Tab. 2. Radiocarbon dates from the test trench.
Twelve sherds from the $\mathrm{Aj}$ vide site and four from the PWC site at Hemmor on the eastern side of Gotland were subjected to XRF-analysis (Fig. 
5). Several of the Ajvide sherds were from the case study area. This analysis measures the levels of various elements in the core of the sherds. Three sets of analyses were made and a mean value calculated. The analysis of the sherds from Ajvide suggests that the clay might have been derived from different clay sources. Thin-section analyses of pot-sherds from Ajvide site are underway which might support or refute this interpretation. TCT tests (Thermal Color Tests) by Österholm $(1989.99,116-117)$ indicate that the pottery at Ajvide was made with clay from three different sources and that the earlier pots (MN A) were more durable ware than the younger examples. The clay in the four Hemmor sherds seems to be more homogeneous and could have come from one clay source, but further analyses are needed to confirm this. Thin-section and inductively coupled plasma mass spectrometry (ICP-measures the levels of various elements in the core of the sherds) analyses on seven sherds with cord imprints from the Stora Förvar cave site indicate that the analysed raw material came from four different clay sources on Gotland (Palmgren 2015.11). In addition to this, one sherd displayed clay that is unknown in Gotland. Due to the imprints and low calcium value of this sherd, it has been interpreted as deriving from a BAC context on the Swedish mainland (Fig. 6). Stora Förvar cave site is probably a place where several groups from around the island and from the Swedish mainland met and brought their locally made pottery. The Ajvide site is probably connected to Stora Förvar, since it is the closest PWC site to this islet site. Further petrochemical analysis and thin sections are needed to confirm the above suggestions.

\section{The FBC and the PWC culture on Gotland}

The largest known FBC on Gotland site is Mölner/ Gullarve, located in Väte parish (Fig. 3). This site has been dated to the Early Neolithic $(c .7000-5500 \mathrm{BP})$ (Österholm 1989.82); the dates are not conclusive and have large ranges, and according to Lidman's study some of the pottery on the site could derive from the early MN A phase (Lidman 2014). One megalithic site with around 30 interred individuals has been located on Gotland; it has been excavated and dated to $c$. 5300-5200 BP (Wallin, Martinsson-Wallin 1997; Martinsson-Wallin, Wallin 2010). Isotope analyses (13C values) of the human skeletal remains from this site show that these people had a terrestrial diet. This contrasts with contemporaneous individuals buried in PWC contexts who had a marine diet. The isotope studies in conjunction with genet- ic analysis and an extensive dating programme of the human skeletal remains from the Neolithic sites on Gotland comprise an ongoing project that will provide further data on this dynamic phase (Paul Wallin, 2014, pers. comm.) (Wallin 2015; Wallin in press; Wallin, Martinsson-Wallin in press).

Some of the PWC skeletal remains at the Ajvide site have been subjected to DNA analyses, and in comparisons with FBC groups on the Swedish mainland, the Ajvide people show a closer genetic similarity to people now living in the Baltic area (Malmström et al. 2009; Skoglund et al. 2012). The result of the genetic studies of PWC mid-Neolithic individuals from Ajvide also show that nine out of ten (six from $\mathrm{Aj}$ vide) lack the T-allele, which has been associated with the ability of adults to consume unprocessed milk (Malmström et al. 2010). This indicates the presence of adult lactose intolerance among the PWC population. The extremely low presence of cattle bones on the sites probably suggests that these animals were mainly kept for meat production for feasting, and/or as status objects and does not indicate milk-production in the first place. According to this study, the PWC groups seem to have originated from a Eurasian hunter-gather population. The prevailing view is that the PWC groups and/or their cultural traits spread from the east coast of the mid-Sweden area southwards and also to Gotland Island.

FBC groups that preceded and were partly contemporary with the $\mathrm{PWC}$, as well as subsequent $\mathrm{BAC}$

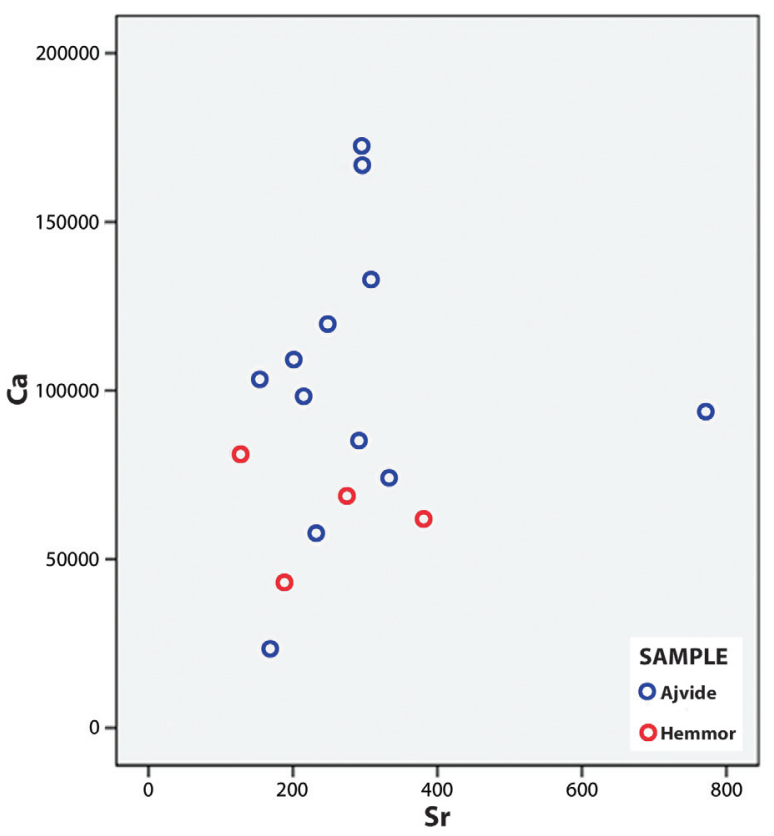

Fig. 5. XRF-analysis on pottery from the Hemmor and Ajvide sites. 


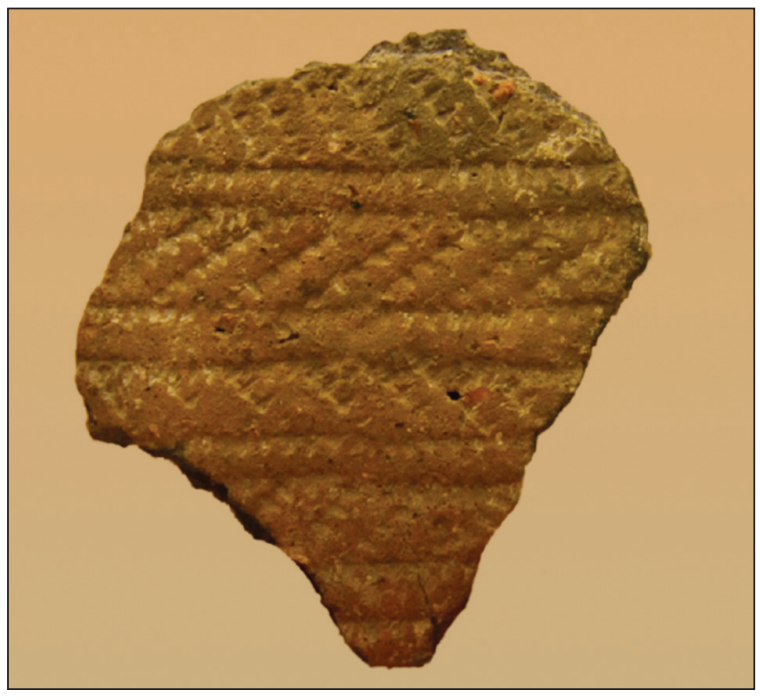

Fig. 6. Sherd from Stora Förvar cave site, most likely manufactured by the BAC on the Swedish mainland (photo: Erik Palmgren).

groups, used pottery with cord imprints. However, the cord imprints of the $\mathrm{FBC}$ differed from the $\mathrm{BAC}$ (Larsson 2009) and, for example, the latter is always left-twisted (Larsson 2009.242-247). The PWC groups, especially on the mainland, seem to have avoided using cord imprints and also differed from the FBC and BAC traditions in that their ware had convex bases.

There are also traces of crop grain imprints in corded ware from the early Neolithic on Gotland (Österholm 1989.84). This, together with the evidence of the megalith grave and the isotope analysis, indicate that people moved in from the south and introduced a farming lifestyle on Gotland in the Early Scandinavian Neolithic. However, as discussed above,

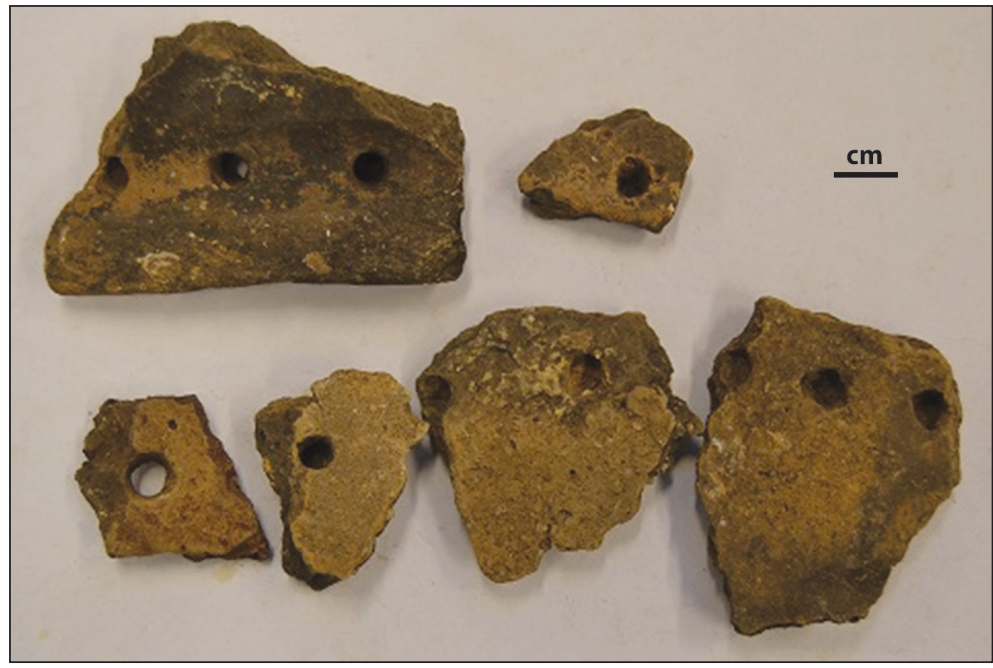

Fig. 7. Typical PWC pottery from the test trench (photo: Erik Palmgren). they are not the ancestors of the mid-Neolithic PWC groups, and these farming communities did not seem to succeed very well in the long run. Current research suggests that the FBC and PWC were two distinct groups with different lifestyles on Gotland at the beginning of mid-Neolithic and that the PWC groups eventually spread all over Gotland, probably at the expense of the farming communities. So far, there is no material or genetic evidence that FBC and PWC groups mixed. The PWC groups spread over the island and became the dominant and only culture during the next 500 years.

\section{Evidence of BAC influences during the MN B phase on Gotland}

The late mid-Neolithic (MN B $c$. 4800-4300 BP) has been discussed as a time when major changes in the material culture occurred on Gotland after around 500 year of PWC tradition. At the end of the MN B, the PWC and the Battle-Axe Culture (BAC) co-existed on the Swedish mainland. The latter show influences from Corded Ware/Single Grave culture (SGC) groups in south Scandinavia, but in an east Scandinavian setting, this culture has been called the Battle-Axe tradition, also with influences from the east (Malmer 2002).

As mentioned above, a few artefacts found at Ajvide and at other Gotland PWC sites are typical of the BAC. Comparisons with artefacts found in the southern Swedish mainland and Denmark show that it is likely that contacts between Gotland and these areas were of equal importance during the early MN $B$ phase. These contacts are, for example, shown in early types of four battle-axes and the two faceted grindstones that were found in graves at what have been interpreted as PWC sites. In the late MN B, phase it seems that contacts with the southern Swedish mainland increased, while contacts with Denmark ceased (Palmgren 2014a).

A total of 60 battle-axes have been found on Gotland, of which 56 are stray finds, and around 50\% are complete (Palmgren 2014.69). Only one example can be tied to an origin from the Danish SGC; the remainder are of a type tied to the Swedish BAC. Four axes found in graves are shaped like early models, but the stray finds are of the middle or late 
models (Palmgren 2014a). The same pattern is seen with grindstones (see above) (Palmgren 2014a). An interesting detail is that the faceted grindstones are not made of quartzite, which is the most common material for these types of grindstones at mainland Swedish sites (Lindström, Boije 2000). The grooves on the grindstones also are unique to the Gotlandic specimens. Taking these two facts into account, it is very likely that these grindstones were manufactured on Gotland and used in other ways than the mainland ones.

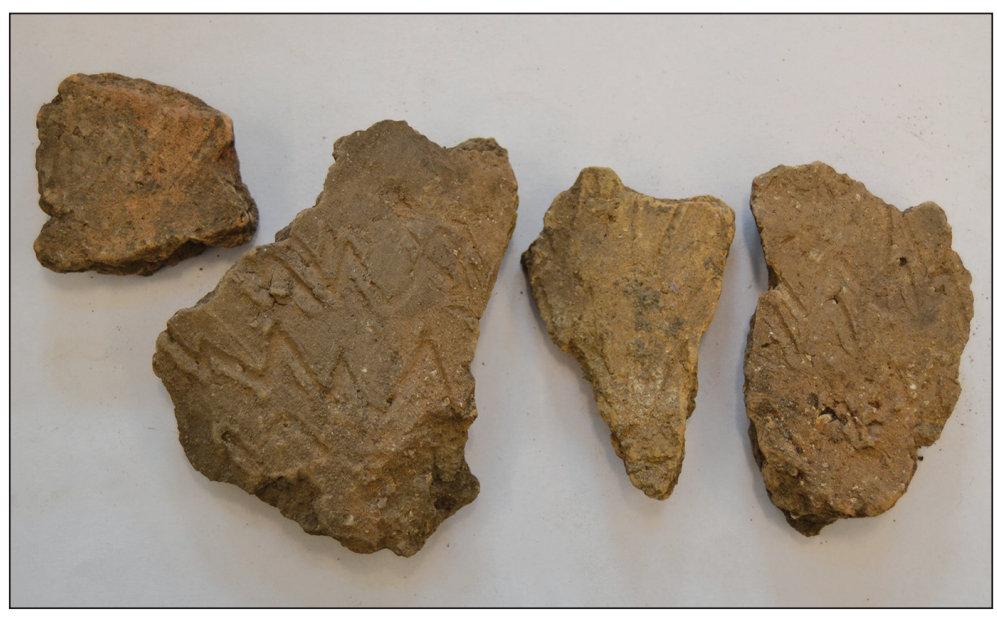

Fig. 8. Pottery with zig-zag patterns from the test trench (photo: Erik Palmgren).

Besides battle-axes and faceted grindstones, finds of five unfinished battle-axes and four reused axes (i.e. with additional shaft holes) (Palmgren 2014a), four-sided bone plates with unique designs, Cerastoderma edule and Dentalium shells (Janzon 1974) and pottery with grog temper (Hulthén 1997) and cord imprints have been found in various PWC contexts on Gotland. So far no evidence that grog temper and cord imprints were used by mainland PWC- groups has been found, but these traits are common among the early mainland BAC-groups (Hulthén 1997). That these features occur on the Gotland PWC sites is probably due to contacts with BAC groups on mainland Sweden (Palmgren 2014a). Another $\mathrm{BAC}$ trait is that the deceased were buried in a crouching position (hocker), which occurs on PWC burial areas on Gotland towards the end of the MN B phase (see above) (Palmgren 2014a).

\section{Gotlandic PWC identity}

The PWC culture seems to have had a strong identity, which was expressed in their pottery, especially the pit design, and a sub-Neolithic lifestyle. Empirical research on artefact assemblages found at PWC sites on Gotland show that with time they became quite different from PWC mainland assemblages (Papmehl-Dufay 2003). The stone axes, grindstones and pottery patterns made by Gotlandic PWC groups in the MN B phase diverge from those made by PWC groups on the mainland (Palmgren 2014; Petrén 1992.35). An explanation could be that Gotland became isolated due to a decline in seafaring, and that interactions with the Swedish mainland thereby ceased. This view is probably not correct, since external interactions are indicated by exotic goods like flint and amber, which are found at PWC sites on Gotland throughout the Neolithic period.
Since an increasing number of sites have been found on Gotland dating to the mid-Neolithic, it has been suggested that the population on Gotland increased during this time. With a growing island population, it might have been of less importance to engage in external contacts with distant family groups on the mainland. Increasing interactivity among the PWC groups on the island could have created a stronger island group identity. Martinsson-Wallin's (2008) study of bone remains from various PWC sites indicated that there could have been three spheres of intra-site interaction, one including sites on the west side, one on the east side and a third towards the north.

Based on the results of analysed material and the discussion above, we suggest that on the one hand it became increasingly important to show an island identity, but at the same time contacts intensified with southern mainland Sweden towards the end of $\mathrm{MN} B$, which are indicated though influenced from the BAC in that area.

In the last phase of PWC, there was a decline in pot decorations in PWC groups on mainland Sweden, (i.e. fewer designs were used). This has been interpreted as the intention of the PWC groups to show group cohesion and homogeneity (Olsson 1997.450) to distinguish them from groups with other cultural affiliations, such as the BAC groups. The cord imprints actually do occur on the Gotland pots from the latter part of the mid-Neolithic (MN B) and the ornamentation on the pots became more varied than at east mainland Sweden PWC sites.

Favouring certain material culture and certain designs are ways to express identity (Hylland Eriksen 2010. 


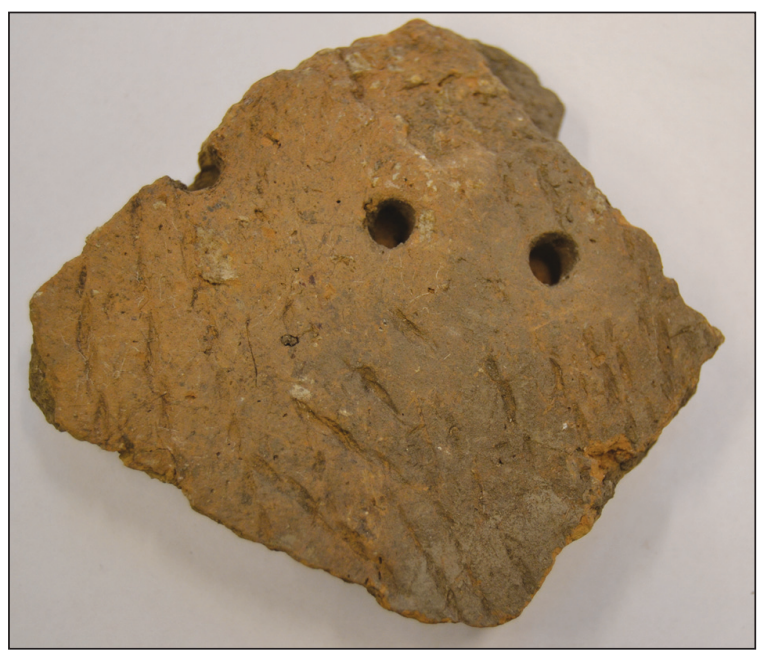

Fig. 9. Pitted pottery with left-twisted cord imprints from the test trench (photo: Erik Palmgren).

345). Based on the analyses and discussion above, we argue that PWC groups on Gotland made conscious choices to decorate their pots in certain ways to strengthen their island identity and that a hybrid culture appeared in the MN B phase on Gotland. Hybridisation is an interesting phenomenon wherein traits or elements meet and form something new. These changes occur in the flow of time when there are interactions between peoples and/or groups of people, but the term has close ties to a post-colonial research strategy (Van Dommelen 2006; Bhahba 2004). We have no evidence that PWC groups were colonised by BAC groups, but rather it seems like a conscious choice by the PWC groups to include BAC material culture. These traits might have come with a few BAC people as marriage partners and/or through new interactions directed to south Scandinavia. We argue that the BAC expressions were 'rephrased' within the frames of the PWC culture to arrive at a localised cultural expression. Hybridisation at the cognitive level and the material expressions attached to this are especially interesting as they create meaning which is both a part of the local production/consumption system, but also reaches beyond this system (Martinsson-Wallin 2011.102). The hybridisation seen during the MN B phase on Gotland had a strong PWC signature, but the pottery designs became more diverse with time and finally also included BAC cultural traits. This differs from the PWC mainland group strategies, where BAC traits seem to have been avoided. In mainland PWC groups in coastal east Sweden no sherds with corded imprints have been found so far (Larsson 2009). Perhaps this is a sign that Gotland PWC groups wanted to distance themselves from earlier allies and kin.

The analysis of late MN B PWC pot sherds at Ajvide show an increasing quantity of corded ware and some new techniques that could be associated with the BAC culture. The difference shown between the Ajvide corded ware and the mainland BAC corded ware tradition is that the former used both righttwisted and left twisted cord imprints, but mainland BAC corded ware bears only left twisted imprints (Larsson 2009). The hybridisation of pottery ornamentation designs found at Ajvide in the last part of MN B combines pits and cord imprints that are both right- and left-twisted, and also in some cases a clay slip and rougher surface occur only on Gotland and not on the Swedish mainland PWC sites. In comparison with the PWC tradition, it is considered that the BAC tradition hadstricter rules regarding material and social culture (Malmer 2002). The current research does not support the notion that the mainland PWC groups changed into the $\mathrm{BAC}$, although at the end of the MN B, BAC pottery sherds have been found at a few mainland sites with PWC influences, termed a 'third group pottery' (Larsson, Graner 2010). So far, no PWC pottery with BAC influences has been found on the mainland, and comparisons with 'third group pottery' sherds on mainland sites have been found only in small numbers. The 'third group pottery' also seems to have been in use over a short period.

\section{Conclusion}

Even if FBC groups with corded ware were contemporaneous with PWC groups on Gotland in the early MN A phase, there are really no indications that the PWC groups were influenced by, or mixed with, FBC groups. The analyses of pottery ornamentation designs from the PWC site at Ajvide show that the sherds with corded imprints were in fact influenced

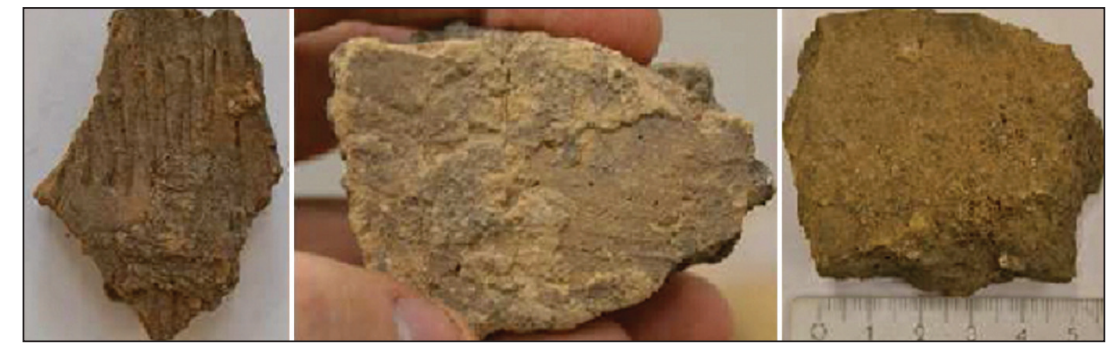

Fig. 10. Three sherds with an extra coarse slip of clay (barbotine) from the test trench (photo: Erik Palmgren). 
by the BAC tradition, since they are found in contexts that date to late $\mathrm{MN} \mathrm{B}$. The analysis of other types of material remains, such as battle axes, facetted grindstones and grave positions (crouching position) of the dead supports the hypothesis that there are BAC influences and traits in the late phase of PWC on Gotland. Since the corded imprints are both right- and left-twisted and found in combination with pit imprints in the Ajvide sample, this suggests the emergence of a hybrid culture where the PWC groups incorporated elements of the BAC cord imprint traditions. The BAC cored ware tradition on the other hand was always left-twisted, but PWC groups on Gotland made conscious choices to include these traits to arrive at new symbolic expressions. The argument that a hybrid culture emerged on Gotland in the MN B is also supported both by the finds of a few burials in the crouching position, which is a BAC trait, but they were facing north rather than east, as well as the use of local material and variations in the shape of the groves of the facetted grindstones. The hybrid culture that emerged on Gotland in the MN B diverge from the pattern of PWC and BAC groups on mainland Sweden, and we suggest that this was a way for the PWC groups on Gotland to strengthen their island identity and also show that external interactions changed focus from east mainland Sweden to south Scandinavia.

We thank Berit Wallenberg's foundation for financial support to make the XRF analyses in this study.

\section{References}

Ajvide Database 2009. Complete database from the Ajvide excavations. University of Gotland. Visby.

Axelsson T., Strinnholm A. 2013. The use of amber in the Scandinavian stone age. In J. A. Bakker, S. B. C. Bloo and M. K. Dütting (eds.), From Funeral Monuments to Household Pottery Current advances in Funnel Beaker Culture (TRB/TBK) research. Proceedings of the Borger Meetings 2009, The Netherlands. British Archaeological Reports IS 2474. Archaeopress. Oxford: 143-150.

Bhabha H. 2004. The location of culture. Routledge. London and New York.

Burenhult G. (ed.) 2002. Remote Sensing. Vol. II. Theses and Papers in North-European Archaeology 13:b. Department of Archaeology, Stockholm University. Stockholm.

Eriksson G. 2004. Part-time farmers or hard-core sealers? Västerbjers studied by means of stable isotope analysis. Journal of Anthropological Archaeology 23: 135-162.

Hallgren F. 2011. Om gropkeramik och dess relation till äldre keramik-hantverkstraditioner kring Östersjön. In P. Bratt, R. Grönwall (eds.), Gropkeramikerna seminarierapport 2011, nr 6. JustNU Centralen. Stockholms läns museum. Stockholm: 32-40.

Hulthén B. 1997. Stenålderskeramiken från Ire på Gotland. In A. Åkerlund, S. Bergh, J. Nordbladh and J. Taffinder (eds.), Till Gunborg arkeologiska samtal. Stockholm University Archaeological Reports 33. Stockholm: 131-145.
2011. Keramiken från Snårarp. In B. Hulthén, A. Edring (eds.), Snårarpskeramiken en aktivitetsbunden produktion. Regionmuseet Kristianstad. Landsarkiven i Skåne: 11-35.

Hylland Eriksen T. 2010. Small places large issues. An introduction to Social Anthropology. Pluto Press. London, Sterling, Virginia.

Janzon G. 0. 1974. Gotlands mellanneolitiska gravar. Acta Universitetis Stockholmiensis. Stockholm.

Larsson Å. M. 2009. Breaking and Making Bodies and Pots. Material and Ritual Practice in Sweden in the Third Millennium BC. AUN 40. Department of Archaeology and Ancient History. Uppsala University. Uppsala.

Larsson A. M., Graner G. 2010. More than meets the eye. In Å. M. Larsson, L. Papmehl-Dufay (eds.), Stone Age Societies in the Baltic Sea Region. Uniting sea II. OPIA 51. Department of Archaeology and Ancient History. Uppsala University. Uppsala: 213-247.

Lidman E 2013. Gömt bakom symbolen. En studie om gropkeramisk dekor på Gotland. Bachelor Diploma Thesis. Uppsala Universitet. Campus Gotland. Visby. http:// www.diva-portal.org/smash/get/diva2:628831/FULLTE XT01.pdf

2014. Kulturen med twist En studie av fyra lokal från trattbägarkulturen på Gotland. Master Thesis. Uppsala Universitet. Campus Gotland. Visby. Online http:// www.diva-portal.org/smash/get/ diva2:726448/ FULLTE XT01.pdf 
Lindström J., Boije M. 2000. Ett dödshus från stridsyxetid. In P. Bratt, J. Lindström and Å. Lundström (eds.), Ett dödshus från stridsyxetid arkeologisk delundersökning av $R A \ddot{A} 415$, ett neolitiskt dödshus med offerplats och en äldre järnåldersboplats samt RÄ̈ 319:2, en stensträng, Söderby 2:3, Turinge socken. Nykvarns kommun, Södermanland. Stockholms Läns Museum. Stockholm.

Martinsson-Wallin H. 2008. Land and sea animal remains from Middle Neolithic Pitted Ware sites on Gotland Island in the Baltic Sea, Sweden. In G. Clark, F. Leach and S. O'Connor (eds.), Islands of Inquiry: Colonisation, Seafaring and the Archaeology of Maritime Landscapes. Terra Australis 29. Australian National University. Canberra: 171-183. Online: http://press.anu.edu.au?p=26551

2011. The Complexity of an Archaeological site in Samoa. The Past in the Present. In J. Liston, G. Clark and D. Alexander (eds.), Pacific Island Archaeology in the 21st Century. Archaeology, Identity and Community. Terra Australis 35: Australian National University. Canberra: 101-114. Online: http://press.anu.edu.au?p= 147701

Martinsson-Wallin H., Wallin P. 2010. The story of the only (?) megalith grave on Gotland Island. Documenta Praehistorica 38: 77-84.

Martinsson-Wallin H., Wallin P. and Apel J. 2011. Prehistoric Lifestyles on Gotland - Diachronic and Synchronic Perspectives. Archaeologia Lituana 12: 142-153.

Malmer M. P. 2002. The Neolithic of South Sweden. The Royal Swedish Academy of Letters, History and Antiquities. Stockholm.

Malmström H., Gilbert T. M. P., Mark G., Brandström M., Storå J., Molnar P., Andersen P. K., Bendixen C., Holmlund G., Göterström A. and Willerslev E. 2009. Ancient DNA Reveals Lack of Continuity Between Neolithic Hunter-Gatherers and Contemporary Scandinavians. Current Biology 19: $1-5$.

Malmström H., Linderholm A., Lidén K., Storå J., Molnar P., Holmlund G., Jakobsson M. and Götherström A. 2010. High Frequency of Lactose Intolerance in a Prehistoric Hunter-Gatherer Population in Northern Europe. Evolutionary Biology 10:89. doi:10.1186/1471-2148-10-89

Norderäng J. 2009. Ajvideboplatsen Rapport från arkeologisk undersökning 2008 av fornlämning $n r .171$ på fastigheten Ajvide 2:1 i Eksta socken, Gotland. Högskolan på Gotland. Visby. Online:http://www.diva-portal.org/ smash/get/diva2:276871/FULLTEXT01.pdf

Olsson E. 1997. Nivå, kronologi och samhälle om östsvensk gropkeramik. In A. Ảkerlund, S. Bergh, J. Nordbladh and
J. Taffinder (eds.), Till Gunborg arkeologiska samtal. Stockholm University Archaeological Reports 33. Stockholm: 441-453.

Palmgren E. 2014a. Den gotländska stridsyxekulturen migration, interaktion eller regionalitet. One year Master thesis. Uppsala University. Uppsala. Online http://www. diva-portal.org/smash/get/diva2:704458/FULLTEXT01. pdf

2014b. Skärvor $i$ både vått och torrt-En detaljundersökning av ett provschakts keramik vid Ajvidelokalens västra strand. One year Master thesis. Uppsala University. Uppsala. Online: http://www.diva-portal.org/ smash/get/diva2:732748/FULLTEXT01.pdf

2015. Delrapport 1 inom projektet: Stora Förvar, en regional eller interregional stenålderslokal? Unpublished report.

Papmehl-Dufay L. 2003. Stone Age Island Archaeology Aspects on Insularity, Cultural Identity and Cosmology during the Neolithic on the Island of Öland in the Baltic. In C. Samuelsson, N. Ytterberg (eds.), Uniting Sea Stone Age Societies in the Baltic Sea Region. Proceedings from the first uniting sea workshop at Uppsala University, Sweden, January 26-27, 2002. Wikströms. Uppsala: 180-203.

Papmehl-Dufay L., Stilborg O., Lindahl A. and Isaksson S. 2013. For Everyday Use and Occasions. A Multi-Analytical Study of Pottery From Two Early Neolithic Funnel Beaker (TRB) Sites on the Island of Öland, SE Sweden. In B. Ramminger, O. Stilborg and M. Helfert (eds.), Naturwissenschaftliche Analysen vor- und frühgeschichtlicher Keramik III: Methoden, Anwendungsbereiche, Auswertungsmöglichkeiten. Band 238. Dr. Rudolf Habelt GMBH. Bonn: 123-152.

Skolglund P., Malmström H., Raghavan M., Storå J., Hall P., Willerslev E., Gilbert M., Thomas P., Götherström A and Jakobsson M. 2012. Origins and Genetic Legacy of Neolithic Farmers and Hunter-Gatherers in Europe. Science 336: 466-469.

Stenberger M., Dahr E. and Munthe H. 1943. Das Grabfeld von Västerbjers auf Gotland. Kungl. Vitterhets historie och antikvitets akademin. Wahlström \& Widstrand. Lund.

Strinnholm A. 2001. Bland säljägare och färfarmare struktur och förändring $i$ Västsveriges mellanneolitikum. Wikströms. Uppsala.

Thorsberg K. 1997. Den gropkeramiska kulturens o-väsen. In A. Åkerlund, S. Bergh, J. Nordbladh and J. Taffinder (eds.), Till Gunborg arkeologiska samtal. Stockholm archaeological reports $\mathrm{nr} 33$. Arkeologiska rapporter och 
meddelanden från institutionen för arkeologi vid Stockholms universitet. Stockholm: 49-57.

Petrén M. 1992. Neolitiska yxor från Gotland form och fördelning. Unpublished BA Thesis. Department of Archaeology. Uppsala University. Uppsala.

Van Dommelen 2006. Colonial Matter. Material Culture and Postcolonial Theory in Colonial Situations. In C. Tilley, W. Keane, S. Kuechler-Fogden, S. Rowlands and P. Spyer (eds.), Handbook of Material Culture. Sage Books. London: 104-124.

Wallin P. 2010. Neolithic Monuments on Gotland: Material Expressions of the Domestication Process. In H. Martinsson-Wallin (ed.), Baltic Prehistoric Interactions and Transformations. The Neolithic to the Bronze Age. Gotland University Press 5. Visby: 39-62.

2015. Perfect Death: Examples of Pitted Ware Ritualisation of the Death. In K. von Hackwitz, R. PeyroteoStjerna (eds.), Ancient death Ways. Proceedings of the workshop on archaeology and mortuary practices. Opia 59. Department of Archaeology and Ancient History. Uppsala University. Uppsala: 47-64.

in press. The Use and Organisation of Middle-Neolithic Pitted Ware coastal site on the Island of Gotland in the Baltic Sea. In C. Dupont, G. Marchand (eds.), Sea People; archaeology of maritime hunter-gatherers - from settlement function to the spatial organisation of the coastal zone. Séance de la Société Préhistoric Fransoise. Renne.

Wallin P., Martinsson-Wallin H. (in press). Collective Spaces and Material Expressions: Ritual Practice and Island Identities in Neolithic Gotland in the Baltic Sea. In G. Nash, A. Townsend (eds.), De-coding rituals in Neolithic Island Societies. Oxbow books. Oxford.

Welinder S. 1973. Om den gropkeramiska kulturen. In P. Simonsen, G. Stamsö Munch (eds.), Bonde - veidemann. Bofast - icke bofast i nordisk forhistorie. Tromsö museums skrifter XIV. Tromsö: 54-59.

Ytterberg N. 2007. Östsvensk neolitisk keramik i Bagges efterföljd. In N. Stenbäck (ed.), Stenåldern $i$ Uppland uppdragsarkeologi och eftertanke. Volym 1 Arkeologi E4 Uppland studier 1 Riksantikvarieämbetet, Societas Archaeologica Upsaliensis, Uppland Museum. Uppsala: 369-409.

Österholm I. 1989. Bosättningsmönstret på Gotland under stenåldern en analys av fysisk miljö, ekonomi och social struktur. Thesis and Papers in Archaeology 3. Stockholm University. Stockholm.

2008. Jakobs/Ajvide undersökningar på en gotländsk boplattsudde från stenåldern. Gotland University Press Monograph 3. Hässleholm. 